\title{
The Sixth National Assembly and Constitutional Amendment in Nigeria- A New Era or a Fait Accompli?
}

Hassan I. Adebowale*

Senior Lecturer Department of Private Property Law, Adeleke University, Ede, Osun State

DOI: 10.36348 /SIJLCJ.2019.v02i10.005 $\quad$ | Received: 15.10 .2019 | Accepted: 22.10 .2019 | Published: 27.10 .2019

*Corresponding author: Hassan I. Adebowale

\section{Abstract}

The history of constitutional development in Nigeria reveals the tortuous road the legislators have taken to bestow a legacy of a befitting Constitution. Constitutional provisions on amendment are tedious, and sometimes, manifestly insurmountable. It therefore behoves the National Assembly to painstakingly adhere to the various provisions of the Constitution in order to fill the lacunae in the Nigeria corpus juris which has constantly plagued the country's political, judicial and socio-economic sectors. From the colonial era, it has always been the same story of exploring different types of constitution. This "try and error" approach has never yielded any acceptable grundnorm for the Federal Government of Nigeria. The peculiar composition of Nigeria as a multilingual, multi-culture and religiously diversified country has virtually been cited as the key issue in Nigeria's tortuous road to a satisfactory constitutional achievement. The much touted "unity in diversity" has proved to be nothing more than political slogan. With the pervasive cry for restructuring in Nigeria, and the continuous failure of successive governments to find sustainable solutions to the yearnings and cravings of the citizenry, this writer looks back at where it all went wrong. This article identifies the obvious sections of the Constitution to be amended by the National Assembly. The author commends the effort of the defunct Sixth National Assembly by its wide consultation and vigorous drive to sensitize numerous interest groups in Nigeria. The general conclusion is based on the views of constitutional experts in Nigeria and some notable judicial pronouncements. The recommendation, however, is that some identified provisions of the Constitution needs further amendment to simplify the mode of constitutional amendment in the nearest future.

Keywords: Constitution, Amendments, Judicial, Government, Consultations, Geopolitical.

Copyright @ 2019: This is an open-access article distributed under the terms of the Creative Commons Attribution license which permits unrestricted use, distribution, and reproduction in any medium for non-commercial use (NonCommercial, or CC-BY-NC) provided the original author and source are credited.

"The fault is not in our stars, but it is in ourselves, that we are underlings"

\section{The chequered history of nigeria's constitutional development}

The historical background to this study can be succinctly phrased "in the beginning ... there was crisis". Since independence, Nigeria has experimented with five constitutions $\left[{ }^{1}\right]$. Although, a Constitution Drafting Committee was set up by the then head of state $\left[{ }^{2}\right]$ it never saw the light of day. The 1999 Constitution, however, heralded the Fourth Republic. The 1960 and 1963 Constitutions were drafted during civilian regime. The 1979, 1989 and 1999 constitutions, on the other hand, came into force during military era. Constitutional issues generated threats to federal unity

\footnotetext{
${ }^{1}$ 1960, 1963, 1979, 1989 and 1999 Constitutions.

${ }^{2}$ General Ibrahim Gbadamosi Babangida (Rtd).
}

between 1960 and $1966\left[{ }^{3}\right]$ manifesting in ethnic rivalry, factionalism and the desire for autonomy within the federal system $\left[{ }^{4}\right]$.

One of the earliest challenging issues was the minority question $\left[{ }^{5}\right]$. This was greatly responsible for most of the political and constitutional problems between 1960 and 1966. Major General Thomas Aguiyi Ironsi set up a Constitutional Study Group Committee under the chairmanship of Chief F.R.A Williams, to

\footnotetext{
${ }^{3}$ Under the civilian rule of Prime Minister Tafawa Balewa (Northern Peoples' Congress) and Dr. Nnamdi Azikwe (National Council of Nigeria and the Cameroon).

${ }^{4}$ This led to political groupings and alliances .

5 Its gravity led to the setting up of the Willinks Commission of Inquiry from 1957 to 1958.
} 
identify the constitutional problems in the light of one Nigeria $\left[{ }^{6}\right]$. Ironsi later promulgated the Constitution (Amendment and Modification) Decree No. 1 of 1966, which amended and modified the constitution of the Federation and those of the regions. He also promulgated the State Securities (Detention of Persons) Decree No. 3 of $1966\left[{ }^{7}\right]$. These decrees survived various military interventions in Nigeria under several guises until May 29, 1999 when a civilian government took over.

Lt. Col. Yakubu Gowon set up an Ad Hoc Constitutional Conference with representatives from all the four regions of the Federation $\left[{ }^{8}\right]$. The focal point at the conference was that of an ideal structure for the country $\left[{ }^{9}\right]$. The military handed over power to a civilian administration in 1979 and also promulgated the Constitution (Amendment and Modifications) Decree of 1979 which brought into operation the Constitution of the Federal Republic of Nigeria 1979.

\section{Constitutional amendment or restructuring?}

Amendment denotes a small change or improvement that is made to a law or document; the process of changing a law or a document, whilst, to restructure means to organize in a new and different way $\left[{ }^{10}\right]$. The word 'amendment' therefore connote that the old constitution survives without loss of its identity despite the change and continues even though it has been subjected to alterations. Consequently, the basic structure or frame work of the old constitution cannot be destroyed and done away with; it is retained albeit in the amended form $\left[{ }^{11}\right]$. Restructuring, however, utterly alters the basic structure of the constitution. It is a complete and fundamental system introduced into the mode of governance $\left[{ }^{12}\right]$ Constitutionally, the National Assembly was set up to make laws for the peace, order

\footnotetext{
${ }^{6}$ Major General Aguiyi Ironsi came to power by the military coup of January 15, 1966 and took over power from the Council of Ministers in Lagos on January 17, 1966.

${ }^{7}$ Which made provisions for the arrest and detention of persons in what was tagged "the interest of the security in Nigeria".

${ }^{8}$ Lt. Col. Yakubu Gowon came to power through the counter coup in July 1966

9 The deliberation of this Committee was short-lived as a result of diverse disagreements and outbreak of the civil war.

${ }^{10}$ Oxford Advanced Learner's Dictionary of Current English, Sixth Edition.

11 Vanguard Newspaper, September 19, 2008, p 24Paper presentation by Ledum Mitee, MOSOP President at the South-South Legislative Review organized by Vanguard.

${ }^{12}$ For instance, changing a whole system of governance from parliamentary to presidential.
}

and good government of the federation $\left[{ }^{13}\right]$.The National Assembly was not set up for the purpose of a holistic review or restructuring of the constitution $\left[{ }^{14}\right]$. It is logical therefore, that constitutional review in the mold of the ill-fated third term amendment is outside the social contract by which members of the National Assembly derive their powers. This cannot be done by the National Assembly. They have no authority or mandate to give a new constitution. They can, however, exercise their power of law making to enact a bill setting up a National Conference to review and restructure the constitution $\left[{ }^{15}\right]$.

\section{THE 1999 CONSTITUTION}

The 1999 Constitution has been heavily criticized for being a military imposition. The then military junta $\left[{ }^{16}\right]$ announced the amendments on the day they lifted ban on politics, therefore, shifting attention from its flaws. The drafters of the 1999 Constitution $\left[{ }^{17}\right.$ ] claimed that after drafting the constitution and submitting same to the military, the military made 17 fundamental amendments to it. These amendments were so critical and crucial that they destroyed the delicate balance they proposed.

The first weakness of the 1999 constitution was its recital that "WE THE PEOPLE of the Federal Republic of Nigeria"; this is fraudulent and presented a faulty foundation for a workable constitution. The people of the Federal Republic of Nigeria never met to enact and give ourselves the constitution. There was no election where delegates were elected for this purpose. The 1999 constitution, thus, is self-contradictory; it has, therefore, been referred to as a piece of military colonialism, flawed and absolutely untenable constitution for a federal situation $\left[{ }^{18}\right]$. With its list of antagonists increasing every day, the amendment of the 1999 constitution was long overdue. The then Senate President, David Mark [ $\left.{ }^{19}\right]$ had said that operators of the constitution have discovered certain areas of defects after practicing the document and were resolute in making the required changes. He noted quite correctly that Nigerians agree that the 1999 Constitution is not a perfect document, as it is neither the product of plebiscite nor a national conference. The Constitution,

\footnotetext{
${ }^{13}$ Section 4, 1999 Constitution of the Federal Republic of Nigeria (promulgation) Decree No. 24.

${ }^{14}$ Ibid, section 9.

15 The Guardian, Tuesday, October7, 2008,p. 99Excerpts of interview granted to Chief Ladi Williams (SAN) Secretary of the Patriots.

${ }^{16}$ Under General Abdulsalam Abubakar (Rtd).

17 See Chief Richard Akinjide's interview, Sunday Tribune, $18^{\text {th }}$ July, 2010,pp. 23 and 28.

18 See Professor Akinwande Oluwole Soyinka's interview, the Guardian, Sunday, July 25, 2010, p. 66.

19 At the inauguration of the Senate Committee on Federal Character and Inter - Governmental Affairs in October, 2007.
} 
he said, was bequeathed to Nigerians in 1999 by the departing military and promulgated into law by military fiat. He said further that "The military who wrote the constitution did their best with the document and the civilians who have been operating it have also tried to ensure that it works, but this is the first time we are operating the constitution and we have come to realize the need to amend it". He concluded that the contradictions inherent in the constitution have made a review compelling and urgent.

\section{THE JOURNEY SO FAR}

Four major attempts have been made to amend the constitution in the past one decade:

1. The Presidential Committee - the first was the Presidential Committee on the Review of the 1999 Constitution set up in 2001 by the Obasanjo administration. The body was impaneled two years ahead of the 2003 general elections. The then President, Olusegun Obasanjo had inaugurated an inter-party committee $\left[{ }^{20}\right]$ that went round the six geo-political zones in the country, collating views on the specific areas of the 1999 constitution that require amendment. The committee indeed did its work, and produced a document, but there was conflict as to whether the former president had not constitutionally usurped the functions of the National Assembly by setting up the committee. Thus, the work of this review committee inaugurated during fourth National Assembly [ $\left.{ }^{21}\right]$ was inconclusive and all its efforts were wasted.

2. The National Assembly Initiative - then followed the National Assembly initiative. The executive team had toured the country and laid the distilled document before the two chambers of the federal legislature. However, the leadership and members thought the executive was blatantly dabbling in what is essentially legislative function and duty. The National Assembly, thus, set up another panel led by the then Deputy Senate President, Alhaji Ibrahim Mantu, to review the constitution and expunge the sections considered cumbersome or contradictory to the tenets of democracy.

3. The National Political Reform Conference Oblivious of the work done by the earlier Presidential Panel and the Mantu Committee, midway through the second tenure of President Obasanjo[ ${ }^{22}$ ] a National Political Reform Conference was convoked. Its term of reference was to conduct a holistic reform and refurbishing

\footnotetext{
${ }^{20}$ Deeply involving the leaders of the then registered three political parties.

$211999-2003$.

22 Obasanjo's second term started in 2003, with renewed efforts at constitution engineering.
}

of the Supreme Law of the Land $\left[{ }^{23}\right]$. The National Assembly set up the Joint Committee on Constitution Review (JCCR) under the leadership of the then Deputy State President $\left[{ }^{24}\right]$. The JCCR embarked on what has arguably, so far, been seen as the most elaborate constitutional amendment bid. These efforts, however, failed not only because of the acrimony and rumpus engendered principally by the proposal for tenure elongation, otherwise popularly known as 'third term' $\left[{ }^{25}\right]$; it also failed because the report proposed; in one fell swoop a basket of 120 amendments. Following the above mentioned disagreements, the National Assembly terminated these efforts on May 16, 2006 $\left[{ }^{26}\right]$; thus throwing away the baby and the bath water.

4. Joint Committee on Constitution Review $\left[{ }^{27}\right]$ - At the inception of the Umaru Musa Yar' Adua / Goodluck Ebele Jonathan administration $\left[{ }^{28}\right]$ the National Assembly indicated that it would resuscitate the bid. On November 20, 2008, a Joint Committee on Constitution Review (JCCR) of the Assembly was constituted with each chamber selecting 44 members under the leadership of the Deputy Senate president, Senator Ike Ekweremadu[ ${ }^{29}$ ] Controversy immediately enmeshed this exercise as a result of the decision of members of the House of Representatives to walk out of the first sitting of the JCCR for refusal of the Senators to recognize the Deputy Speaker, Honourable Usman Bayero Nafada, as coChairman of the JCCR $\left[{ }^{30}\right]$. As a way out, the Senate and the House of Representatives agreed to organize separate programmes on the amendment issue and later come together to harmonize their positions. Ekweremadu took charge of the Senate's

${ }^{23}$ The Conference sat in Abuja between February and July 2005, and came up with far-reaching recommendations

${ }^{24}$ Senator Ibrahin Mantu

25 President Olusegun Obasanjo's obvious attempt to get the section of the Constitution amended to accommodate his ambition to contest the 2007 election.

26 The Constitution Amendment Bill was finally defeated on the floor of the Senate on May 17, 2006.

27 Inaugurated on November 20, 2008 under the leadership of the Deputy Senate President, Senator Ike Ekweremadu.

282007 - 2011

${ }^{29}$ The 88 "wise men" later met in Minna in January 2009 , with a view to mapping out the strategies to accomplish the task.

${ }^{30}$ The Senators had insisted that the idea was strange in legislative practice and that the Senate had always provided chairmen for joint committees while the House provides the vice-chairman. The House of Representatives, on its own part, filed a case in court for the interpretation of sections 4, 52 and 53 of the 1999 Constitution. 
amendment bid, while the Deputy Speaker, Alhaji Usman Nafida was made chairman of the House Committee.

\section{Hearings of the Senate Committee on Constitution Review in the Six Geopolitical Zones}

In October 2009, the Senate Committee on Constitution Review (SCCR) organized a retreat in Kaduna, where its members adopted the procedure to be operated in the constitution review exercise [ $\left.{ }^{31}\right]$. Additionally, each of the Senators was encouraged to visit his constituency and collate the opinions of the people on the way forward on the constitution amendment exercise. In order to tap more from the people, the lawmakers in the upper chamber organized a zonal retreat $\left[{ }^{32}\right]$ where the people were requested to gather at an agreed location in each of the six geopolitical zones to deliberate on the shortcomings of the 1999 Constitution $\left[{ }^{33}\right]$. There was massive turnout of Nigerians at the two-day retreat in the six geopolitical zones. There were diverse views on the proposed amendments just like the variety of tongues in the Nigerian Federation.

From the Enugu sitting, there were calls for states creation and equality of states in the geopolitical zones.

From the Port Harcourt Centre, there were calls for the inclusion of the much-touted resource control on the agenda of the ongoing Constitution amendment. Professor Amos Ituama $\left[{ }^{34}\right]$ advocated for full resource control, state independent electoral bodies and anti-graft agencies.

At Makurdi, a paper was presented by the Benue State governor $\left[{ }^{35}\right]$ clamouring for the retention of the immunity clause and scrapping of independent candidates from the electoral system.

At the Gombe Centre, controversial issues [ ${ }^{36}$ ]were raised bordering on Sharia legal system, electoral reforms, gender equality, immunity clause, composition

\footnotetext{
${ }^{31}$ The Senate President, David Mark, cited the presence and full participation of the State Houses of Assembly at this retreat as part of the consultations made with all stakeholders before arriving at the final bill. He stressed that there had been more engagements between the Committees and the Speakers since then.

${ }^{32}$ December 14 and 15, 2009.

${ }^{33}$ There were sittings in Kano (North-West), Gombe (North-East), Makurdi (North-Central), Enugu (SouthEast), Lagos (South-West) and Port Harcourt (SouthSouth).

34 The then Deputy Governor of Delta State who represented the governor at the occasion.

${ }^{35}$ Honourable Gabriel Suswam.

36 Some Islamic groups and students presented positions.
}

of the Independent National Electoral Commission (INEC) and recognition of the traditional institution by the Constitution.

Reports from the Lagos Centre chaired by the Senate majority leader $\left[{ }^{37}\right]$ indicate that the South-West zone recorded the largest attendance and participation $\left[{ }^{38}\right]$ The then Lagos State Governor, Mr. Babatunde Raji Fashola $\left[{ }^{39}\right]$ wants the state to take control of creation of local governments and the deleting of the names of local governments listed in the Schedule to the Constitution, in line with the spirit of true federalism. He also laments the neglect of Lagos, Nigeria's former Federal Capital, by the Federal Government.

The then Osun State Deputy Governor $\left[{ }^{40}\right]$ called for a new revenue formula, electoral reforms and practice of true federalism. The then Speakers of Ondo and Ekiti Houses of Assembly [ ${ }^{41}$ ] canvassed the institution of true federalism, independence of the electoral commission and local government reforms. The traditional rulers also took time to present issues affecting their domain $\left[{ }^{42}\right]$. The main grouse of the traditional rulers was that the 1999 Constitution completely left out the role of traditional rulers which has hitherto been constitutionally guaranteed as could be seen in the 1979 Constitution of the Federal Republic of Nigeria.

The South-West Zone also witnessed intimidating presence of lawmakers, politicians, members of the civil society, diaspora groups and distinguished individuals. Notable names are Olasupo Ojo [ ${ }^{43}$ ] Senator Femi Okurounm [ $\left.{ }^{44}\right]$, Professor Adebajo $\left[{ }^{45}\right]$ Hakeem Bello $\left[{ }^{46}\right]$ Femi Falana $\left[{ }^{47}\right]$ among others. Their presentations centered on independence of INEC, adoption of the six geopolitical zones as

\footnotetext{
${ }^{37}$ Senator Teslim Folarin.

${ }^{38}$ There were delegations of state governments, Houses of Assembly in the zone, and overwhelming presence of traditional rulers, civil society groups and notable individuals.

${ }^{39}$ The governor presented the State's position at the Conference.

${ }^{40}$ Erelu Olusola Obada presented the Osun State government position.

${ }^{41}$ Honourables Taofeek Olawale and Tunji Odeyemi respectively.

${ }^{42}$ For example, Oba Adedapo Adisa, representing the Ooni of Ife, Oba Okunade Sijuwade strongly felt that it is high time Oduduwa State was created with the headquarters at Ile-Ife which is regarded as the source of all Yoruba.

${ }^{43}$ Representative of the Civil Society Groups.

${ }^{44}$ General Secretary of Afenifere, the pan-Yoruba socio-political organization.

${ }^{45}$ A veteran technocrat.

${ }^{46}$ Representative of Nigeria in Diaspora.

${ }^{47}$ A Lagos - based human right lawyer.
} 
federating units $\left[{ }^{48}\right]$ electoral and political reforms $\left[{ }^{49}\right]$ separation of the position of Attorney General of the Federation (AGF) and the Minister of Justice, inclusion of Nigerians abroad in the electoral plans [ ${ }^{50}$ ] adjustment of rules of electoral tribunals $\left[{ }^{51}\right]$ and cutting down of the country resources on servicing of unproductive civil service $\left[{ }^{52}\right]$

The extent of the impact of these hearings on the amended version of the 1999 constitution is a basis for part of the criticism of the amendment process.

\section{THE AMENDMENTS}

The major amendments that scaled through are:

- Financial Autonomy: The Constitution was amended to ensure financial autonomy for the Independent National Electoral Commission (INEC), Judiciary $\left[{ }^{53}\right]$ and National Assembly $\left[{ }^{54}\right]$.

- Presidential/ Governorship Election $\left[{ }^{55}\right]$ : The Presidential / Governorship elections are to hold 120 - 150 days (Four- five months) to the expiration of the tenure of the incumbents. Second alteration was made to this $\left[{ }^{56}\right]$ providing for the conduct of elections for National Assembly, State Houses of Assembly, President and governorship elections not earlier than 150 days and not later than 30 days to the expiration of the incumbents' tenure of office $\left[{ }^{57}\right]$ new timeline for the conduct of elections was thereby set.

- No Tenure Extension: No tenure extension for sitting president /governor who wins a rerun election $\left[{ }^{58}\right]$.

- Panel Indictments: Panel indictment can no longer be used to disqualify candidates from running for elections $\left[{ }^{59}\right]$. It will now require a court judgment.

\footnotetext{
${ }^{48}$ Wherein, the number of states and local governments would be determined by the Federating units.

49 For instance, re-introduction of Option A4 and parliamentary system of government.

${ }^{50}$ Such that they could be allowed to vote from the embassies.

${ }^{51}$ Such that they can get to the roots of election fraud rather than rely on technicalities.

${ }_{52}$ This is possible by stopping creation of new states.

${ }^{53}$ Section 81 of the 1999 Constitution.

5416 States, apparently under pressure from their governors, voted against financial autonomy for the State assemblies .

${ }^{55}$ Section 132, 1999 Constitution.

${ }^{56}$ The National Assembly bowed to the appeals made by INEC, the political parties and other stakeholders on the extension of time within which to conduct the elections - presentation of the first amendment was made in July, 2010, and the incumbents' tenure expire in June 2011.

${ }^{57}$ Constitution (Second Alteration) Bill, 2010.

58 Section 180, 1999 Constitution of the Federal Republic of Nigeria.
}

- Acting President during temporary absence of President: If the president does not transmit a vacation letter within 21 days, the National Assembly will pass a resolution making the vicepresident the acting president $\left[{ }^{60}\right]$

- Acting Governor during temporary absence of Governor: If the governor does not transmit a vacation letter within 21 days, the state house of assembly will pass a resolution, making the deputy governor the acting governor $\left[{ }^{61}\right]$.

- Original Jurisdiction: Appeal Court is to be the first court of jurisdiction on interpreting the tenure, validity of election and determining if a vacancy exists in the positions of president, vice-president, governor and deputy governor $\left[{ }^{62}\right]$.Arrangements of the sections amended by the $6^{\text {th }}$ National Assembly are as follows $\left[{ }^{63}\right]$ :-

Constitution of the Federal Republic of Nigeria (First Alteration) Act, 2010 - Alteration of sections $66 ; 69 ; 75 ; 76 ; 81 ; 104 ; 110 ; 116,132,135,137$, $145,156,160,178,180,182,190,200,228$ (a) and (b), 229, 233, 239, 246, 251, 272, 285, Alteration of Schedule to the

\section{Constitution and Citation}

Constitution of the Federal Republic of Nigeria (Second Alteration) Act, 2010-

- Alteration of the 1999 Constitution and the Constitution (First Alteration) Act No. 5

- Alteration of section 5 First Alteration Act and section 76 (2) of the Constitution.

- Alteration of section 10 First Alteration Act and section 116 of the Constitution.

- Alteration of section 11 First Alteration Act and section 132 (2) of the Constitution.

- Alteration of section 17 First Alteration Act and section 178 (2) of the Constitution.

${ }^{59}$ Section 66, 1999 Constitution of the Federal Republic of Nigeria.

60 Section 145, 1999 Constitution of the Federal Republic of Nigeria. This amendment is necessitated by the late President Shehu Musa Yar'adua's saga, where his prolonged absence for medical treatments abroad created a constitutional logjam. The National Assembly had to result to the late president's speech in the absence of a written notice, transcribed on British Broadcasting Corporation (BBC) to resolve the impasse.

61 Section 190, 1999 Constitution of the Federal Republic of Nigeria.

62 Section 239, 1999 Constitution of the Federal Republic of Nigeria.

Note that the Constitution (Second Alteration) Bill 2010 allows the Supreme Court to handle governorship election.

${ }^{63}$ See The Constitution of the Federal Republic of Nigeria, 2011 (As Amended). 
- Substitution for section 24 of the Constitution and section 24 of the First Alteration Act.

- Substitution for section 25 of the Alteration Act and section 139 of the Constitution.

- Substitution for section 26 of the First Alteration Act.

- Substitution for section 285 of the Constitution and section 29 of the First Alteration Act

- Substitution and sixth Schedule to the First Alteration Act.

- citation

Some other amended sections are Section 84 (financial autonomy for the remuneration and recurrent expenditure of INEC board members); Section 69 (recall of any member of house of representative / senate will no longer go through referendum); Section 110 (recall of any member of state house of assembly will no longer go through a referendum); Section 156 (members of Federal executive bodies, including INEC, must not belong to any political party); Section 75 (1991 census not to be used as basis for delineating constituencies. Latest census figures should be used); Section 160 (INEC to make rules for itself without presidential interference); Section 200 (members of state executive bodies, including the electoral commission, must not belong to any political party).

\section{SHORTCOMINGS}

\section{Need For a Brand New Constitution}

In the words of Former Chief Justice of Nigeria, Justice Alfa Belgore $\left[{ }^{64}\right]$.

\section{Is our present constitution really working?}

My answer with the greatest respect is that it is far from working. The framers of the 1999 constitution certainly looked across the ocean to borrow constitution totally irrelevant to us. We may make one thousand amendments in our present constitution; we shall still remain with irrelevant documents as our fountain of law $\left[{ }^{65}\right]$.

Honourable Justice S. O Uwaifo (CON) $\left[{ }^{66}\right]$ is also an advocate of a total restructuring of the constitution. In his own words, he would rather prefer a revisit of the constitution as a whole $\left[{ }^{67}\right]$

\footnotetext{
${ }^{64}$ Also the former Chief Judge of the Court of Appeal and Chief Judge Plateau State.

${ }^{65} \mathrm{He}$ made this assertion in Asaba, Delta State Capital as guest lecturer, at the $5^{\text {th }}$ distinguished annual lecture series organized by the Delta State House of Assembly Service Commission on Saturday, $14^{\text {th }}$ August, 2010.

${ }^{66}$ A retired Justice of the Supreme Court of Nigeria

${ }^{67}$ See excerpts in Sunday Tribune, 5 December, 2010 at pg. 42
}

Chief Ladi Williams (SAN) $\left[{ }^{68}\right]$ wants a total overhauling of the constitution. He is particular about restructuring of the system of government, the judiciary and fiscal federalism $\left[{ }^{69}\right]$.

Dr. Lateef Adegbite, the Secretary General of Supreme Council for Islamic Affairs wants a more comprehensive approach in which everybody would be involved instead of picking a few sections in the constitution. According to him, what we need is a brand new constitution and not the piece meal amendment $\left[{ }^{70}\right]$.

\section{Statutory Authority to Amend the Nigerian Constitution}

The 1999 Constitution, being severally battered from different quarters, has obviously woefully failed to meet up with desired expectations. The National Assembly's mandate on constitutional amendment can be viewed in the context of section 9 of the Constitution of the Federal Republic of Nigeria which provides that:

The National Assembly may, subject to the provisions of this section, alter any of the provisions of this Constitution.

In the light of the above provision, it is glaring that the National Assembly has no authority to give a new constitution. A general revisit of the constitution as a whole cannot be done by the National Assembly. The National Assembly can amend one section or the other - it has the power to make and amend laws. They were set up to make laws for the good governance of the country. They were not, therefore, set up for the purpose of a whole scale review and restructuring of the constitution. The National Assembly can, however, exercise its power of law making to enact a bill setting up a National Conference to review and restructure the constitution.

\section{True Federalism}

The Nigerian Constitution $\left[{ }^{71}\right]$, even as amended at the moment, has failed the test of true federalism. Nigeria, unlike its counterparts in U.S.A, Canada and Australia, is not operating a true federal system. The states do not have enough autonomy. The Nigerian Constitution is more centripetal than centrifugal. The Independence Constitution of 1960 was more federal. At independence, apart from the

\footnotetext{
${ }^{68}$ Secretary of the Patriots, a non-partisan group of elder statesmen

${ }^{69}$ A state receiving income according to its contribution to the federation account and according to what is derived from that state. See excerpts in Saturday Tribune, 7 October, 2008 at pg. 99.

${ }^{70}$ See News Star Newspaper, August 4-6 Edition, 2010 at Page 40

71 Though a Federal Constitution.
} 
Constitution of the Federal Republic of Nigeria, the states $\left[{ }^{72}\right]$ had their own Constitutions.

\section{Justice Uwais Committee Report}

The oppositions $\left[{ }^{73}\right]$ have roundly condemned the amendments to the 1999 Constitution for its sharp departure from the recommendations of the Justice Uwais - led Electoral Reform Committee. Arguably, the whole amendment exercise was sparked - off by the Uwais Panel's Report whose recommendations, according to oppositions, have been dumped and personal issues, which were not discussed at the public hearings, have been smuggled in. The Uwais Panel's Report was hailed as comprehensive and satisfactory nationwide. Few of the many 'sins' of the lawmakers are:

- Appointment of INEC Chairman by the President;

- Cross - carpeting of politicians from one political party to the other;

- Blockade on independent candidacy ;

- Allowing those indicted by a judicial or administrative panel of inquiry to run for office;

- The immunity clause for the president (and his vice) and the governor (and his deputy); and, the litany of their 'evil' goes on.

With the above - mentioned loopholes, it is crystal clear that the State Assemblies, for constraint of time, have not done a clause by clause assessment of the bill before adopting and ratifying it as the new Nigerian Constitution $\left[{ }^{74}\right]$.

\section{The President's Assent}

An interesting development in the amendment saga was the controversy on the need for the assent of the President in the final copy of the amendment before it becomes a legal document. The argument championed by the National Assembly's ad-hoc committees for the constitution review is that since $2 / 3$ members of the State Houses of Assembly of the Federation have passed it into law, it automatically

\footnotetext{
${ }^{72}$ Notwithstanding that there were just three states; and later four with the creation of Midwest State.

${ }^{73}$ Political parties, Coalition for Change / Constitutional Reform Dialogue Mechanism (CRDM) through their representative, Dr. Otive Igbuzor. The CRDM comprises Citizens Forum for Constitutional Reform (CFCR), Gender and Constitution Reform Network (GECORN), Joint National Association of People with Disabilities (JONAPWD), Nigerian Labour Congress (NLC), Nigeria Union of Journalists (NUJ), Peoples Constitution Advocacy Group (PECAG), Nigerian Bar Association (NBA) and Electoral Reform Network (ERN).

${ }^{74}$ While the states are said to be conversant with the details of the amendments of the House of Representatives because the technical committee members worked with the House Committee, most of them are not conversant with the Senate's version.
}

becomes fiat accompli $\left[{ }^{75}\right]$. The other school of thought believed that since it is an Act of the National Assembly and for it to be an Act, it needs to be assented to by the President $\left[{ }^{76}\right]$.

The Court however, put an end to this controversy by its ruling on 8 November, 2010. Mr Olisa Agbakoba (SAN) $\left[{ }^{77}\right]$ filed a suit at the Federal High Court, Lagos, challenging the propriety of the decision of the National Assembly not to subject the amended Constitution to presidential assent. He prayed the court to declare that the exclusion by the National Assembly of the assent of the President of the Federal Republic of Nigeria from the process of alteration of the Constitution, unless section 58(5) of the 1999 Constitution is compiled with, renders the "Constitution (First Amendment) Act 2010" embodying such altered provisions unconstitutional, null and void.

Justice Okechukwu Okeke of the Federal high Court in Lagos held that the purported amendment to the 1999 Constitution remains inchoate, until it is presented to the President for his assent, as required under section 58 of the 1999 Constitution. Relying on section 2 of the Interpretation Act, Justice Okeke held that the Constitution, having become law through an Act, can only be amended through an Act. Besides, an Act of the national Assembly cannot become a law without the assent of the president - having failed to comply with the provisions of section 58 of the Constitution, the purported 2010 amended constitution remains inchoate until it is presented to the president for his assent. Justice Okeke, therefore ruled that the National Assembly could enforce the Constitution only through a Constitutional procedure, which allows it to do away with presidential assent, should the president refuse to give his assent to an amended Act after 30 days $\left[{ }^{78}\right]$.

With the above ruling, one of the most crises ridden journeys to constitutional amendment, in the history of the world, was dramatically brought to an end. The ruling paved way for the signing into law of the Constitution 2011 (As Amended) by the Acting

\footnotetext{
${ }^{75}$ This position was supported by some legal luminaries like Chief Bayo Ojo, SAN (former Attorney General of the Federation and Minister of Justice) and Professor I. Sagay (a renowned constitutional lawyer).

${ }^{76}$ Professor Ben Nwabueze (a member of Presidential Advisory Council and a legal luminary) and Chief Oluwarotimi Akeredolu, SAN (Former President of the Nigerian Bar Association) are in support of this position.

${ }^{77}$ A Former President of the Nigerian Bar Association (NBA)

${ }^{78}$ See The Nation Newspaper, 9 November, 2010 ,pp,1 -2 .
} 
Clerk of the National Assembly $\left[{ }^{79}\right]$ and the President of the Federal Republic of Nigeria $\left[{ }^{80}\right]$. However, the fact that most of the cogent issues raised at various geopolitical hearings have not been addressed, makes further future amendments inevitable.

\section{CONCLUSION}

There are more questions, than answers on the numerous issues raised in the different geopolitical hearings on constitutional amendment. More importantly, issues bordering on creation and equality of states, immunity clause, sharia legal system, gender equality, local government reforms, electoral and political reforms, true federalism, resource control, recognition of traditional institutions etc., were left hanging. This calls to question the competence of the National Assembly to adequately address these issues. Section 9 of the Constitution has constrained the power of the National Assembly to mere altering of any provision of the constitution. The inference from this is that the National Assembly can only exercise its power of law making to enact a bill setting up a National Conference to review and restructure the constitution. Any attempt at a holistic review or restructuring of the Constitution by the National Assembly would clearly be outside the social contract by which members of the National Assembly derive their powers.

The interpretation of section 58 of the Constitution by Justice Okechukwu Okeke of the Federal High Court is plausible. An amendment without the subsequent statutory assent of the President of the Federal Republic of Nigeria is inchoate. This pronouncement has underlined the role of the judiciary in unraveling knotty impasse in our body politics.

Finally, this author aligns with the views of Justice Alfa Belgore, Honourable Justice S.O Nwaifo(CON), Chief Ladi Williams(SAN) and Dr. Lateef Adegbite that the Nigerian Constitution, which is neither a product of plebiscite nor a national conference, is long overdue for a holistic reform and refurbishing. Mootly, the catalyst for the clamour for an amendment of the Nigerian Constitution is the Justice Uwais-led Electoral Reform Committee, which was widely acclaimed as comprehensive and satisfactory. Ironically, most of the findings and recommendations of the Uwais Panel's Report were not implemented in the new amendments. Fortuitously, the perennial clamour for the convocation of a sovereign national conference by the civil society and human rights groups, in the light of the various limitations bedeviling the National Assembly, should be considered by the government in order to present Nigerians with a credible and sustainable constitution.

\footnotetext{
${ }^{79}$ Salisu Abubakar Maikosowa (mni), dated $6^{\text {th }}$ day of January, 2011.

${ }^{80}$ Dr. Goodluck Ebele Jonathan (GCFR), dated $10^{\text {th }}$ day of January, 2011.
} 